\title{
ASSESSMENT OF QUALITY CHARACTERISTICS OF BRIQUETTES PRODUCED FROM SELECTED WOOD WASTE
}

\author{
Ignacy NIEDZIÓŁKA ${ }^{\mathbf{1}}$, Maciej SPRAWKAㅜ, Beata ZAKLIKA ${ }^{\mathbf{1}}$, \\ Artur KRASZKIEWICZ ${ }^{2}$ \\ ${ }^{1}$ Department of Agricultural, Forest and Transport Machinery, University of Life Sciences in Lublin, \\ POLAND \\ ${ }^{2}$ Department of Machinery Exploitation and Management of Production Processes, University of Life \\ Sciences in Lublin, POLAND \\ E-mail of corresponding author: ignacy.niedziolka@up.lublin.pl
}

Keywords: agro-energetics, biomass, briquettes, sustainability agriculture

\begin{abstract}
The paper presents evaluation of the quality characteristics of briquettes produced from selected wood waste, whose use is part of a sustainable farming policy. The following types of wood waste were used in the study: poplar sawdust, poplar bark, oak shavings and oak bark. In order to crush the poplar and oak bark, a beater shredder was used. Briquettes were made using hydraulic piston briquetting machine. During the briquetting process, the working pressure was $8 \mathrm{MPa}$. Depending on the type of waste used, the briquettes produced differed in their qualities. Based on the analysis of the obtained results, it was found that the characteristics of produced briquettes were influenced by such factors as the type of raw material, its humidity and fragmentation. The best quality features characterized briquettes made of oak bark and the least advantageous of oak shavings.
\end{abstract}

\section{INTRODUCTION}

The Sustainable Agriculture Strategy fosters environmental protection in rural areas, which is linked to increased use of renewable energy sources. Wood waste is a valuable energy resource and they fit in this strategy. It can be used to produce electricity, heat, and liquid and gaseous fuels. Remnants of the trees, waste from sawmills or branches of orchards can be burned in the form of sliced wood, chips, and processed into pellets or briquettes (Hejft \& Obidziński, 2015; Niedziółka et al., 2016). This allows full use of the raw material. This type of fuel is not harmful to the environment. Carbon dioxide, which is emitted to the atmosphere during combustion, is completely absorbed by plants reproducing biomass in the process of photosynthesis. In addition, wood is the fuel that leaves the minimum amount of ash after burning (Kachel-Jakubowska et al., 2013; Mc Kendry, 2002; Panwar et al., 2011).

Wood, which is a major part of biomass, is the most widely used renewable energy source in Europe. It occurs in the form of shavings from perennial trees (e.g. willow, poplar) as well as chips, sawdust and wood dust (Ivanova et al., 2014). The popular way to use wood fractions is to produce pellets and briquettes for energy purposes. In addition, the generation of energy from wood waste is profitable, because prices of these fuels on the market are competitive relative to fossil fuels (Frączek, 2010; Shawa et al., 2009).

Besides wood waste, straw and specially developed energy crops can be used for the production of heat. These raw materials are the biomass, which is included in renewable energy sources, including solar, geothermal, wind and river energy, agricultural biogas, and landfill and sewage treatment plants (Demirbas, 2004; Dreszer et al., 2003). Poland is characterized by the high potential of biomass used for energy purposes. It has considerable potential for development of agro-energy, especially based on the production of perennial energy crops. Hence, most biomass used for power generation is produced in the country (Kołodziej \& Matyka, 2012; Niedziółka, 2014). 
Solid biofuels made of plant biomass are of particular interest to distributed energy and to individual consumers. At present, professional energy is reluctant to use biomass as a fuel in power systems. This is caused, among others, by lower quality of this kind of fuel and also the instability of its supply. However, it is necessary to look for alternative fuels for the energy sector, hence the aim is to use different types of plant biomass for these purposes. New technological solutions are also sought, using plant fuels to produce electricity and heat. The existing technologies for the management of biomass surpluses from agricultural, forestry and orchard production are also being improved (Fournel et al., 2015; Huiling et al., 2013; Zhang et al., 2013).

The purpose of the study was to analyze the qualities of briquettes produced from selected wood waste in a hydraulic piston briquetting machine.

\section{MATERIAL AND METHODS}

The following wood waste was used for the production of briquettes: poplar sawdust, poplar bark, oak shavings and oak bark. The tree bark was crushed using a beater powered by an electric motor of $5.5 \mathrm{~kW}$ and equipped with a $10 \mathrm{~mm}$ mesh diameter sieve. For the briquetting of raw materials, hydraulic piston briquetting machine was used. During the briquetting process, the working pressure was $8 \mathrm{MPa}$ and the double feed of the feeder to the briquetting compaction chamber, was applied.

The relative humidity of wood raw materials and their calorific value, based on calorimetric measurements, was determined using an iso-perybolic calorimeter. The moisture and heat content of the raw materials were measured in triplicate.

Measurements of physical features of briquettes included: diameter, length and weight. Samples of 10 briquettes were taken and three replicates were used for the measurements. The diameter and length of the briquettes were determined by means of a slide gauge with a measurement accuracy of $\pm 1 \mathrm{~mm}$ and their mass using laboratory scale with an accuracy of $\pm 0.1 \mathrm{~g}$.

The bulk density of briquettes was determined on the basis of measurements of their physical characteristics including diameter, length and weight and then calculated according to formula (1):

$$
\rho_{w}=\frac{4 \cdot 10^{6} \cdot \mathrm{m}}{\pi \cdot d^{2} \cdot l}\left(\mathrm{~kg} \cdot \mathrm{m}^{-3}\right)
$$

where: $\rho_{\mathrm{w}}$ - briquette bulk density $\left(\mathrm{kg} \cdot \mathrm{m}^{-3}\right)$,

$\mathrm{m}$ - mass of briquette $(\mathrm{g})$,

$\mathrm{d}$ - outer diameter of briquette $(\mathrm{mm})$,

1 - length of briquette $(\mathrm{mm})$.

Measurements of mechanical durability of briquettes were carried out on a test bench in accordance with standard PN-EN 15210-2:2011. The rotational speed of the cylinder was $21 \mathrm{rpm}( \pm 0.1 \mathrm{rpm})$, a test time of $5 \mathrm{~min}$, and a sample weight of $2000 \mathrm{~g}( \pm 100 \mathrm{~g})$. After the durability test, the briquettes were screened on a $31.5 \mathrm{~mm}$ diameter screen. The mechanical durability of briquettes was calculated according to the formula (2):

$$
\mathrm{D}_{\mathrm{U}}=\frac{\mathrm{m}_{\mathrm{A}}}{\mathrm{m}_{\mathrm{E}}} \cdot 100(\%)
$$

where: $\mathrm{D}_{U}-$ mechanical durability of briquettes $(\%)$,

$\mathrm{m}_{\mathrm{A}}-$ mass of briquettes after durability test $(\mathrm{g})$,

$\mathrm{m}_{\mathrm{E}}-$ mass of briquettes before durability test $(\mathrm{g})$. 
The results of the tested briquettes were subjected to statistical analysis using variance analysis and Tukey's test. For this purpose, the Statistica ver. 13.1 software was applied and the significance level was assumed at $\alpha=0.05$.

\section{RESULTS}

Prior to the wood waste briquetting process, the moisture content and calorific value were determined. Based on the results obtained, it was found that the moisture content of wood waste used for the production of briquettes ranged from $10.7 \%$ to $14.8 \%$, while their calorific value was within the limits of $15.5-16.3 \mathrm{MJ} \cdot \mathrm{kg}^{-1}$ (Table 1).

Table 1. Relative moisture and calorific value of wood waste

\begin{tabular}{|l|c|c|}
\hline Kind of wood waste & Relative moisture $(\%)$ & Calorific value $\left(\mathrm{MJ} \cdot \mathrm{kg}^{-1}\right)$ \\
\hline Poplar sawdust & 13.4 & 16.3 \\
\hline Poplar bark & 12.6 & 16.1 \\
\hline Oak shavings & 10.7 & 15.5 \\
\hline Oak bark & 14.8 & 15.6 \\
\hline
\end{tabular}

Source: own work

Diameter of the obtained briquettes was constant and was $50 \mathrm{~mm}$. Figure 1 shows average lengths of obtained briquettes. The longest briquettes were made of oak bark $(78.3 \mathrm{~mm})$, much shorter of poplar sawdust $(61.9 \mathrm{~mm})$ and poplar bark $(61.2 \mathrm{~mm})$, while the shortest of oak shavings $(57.5 \mathrm{~mm})$. There were no statistically significant differences between the lengths of briquettes produced from poplar sawdust, poplar bark and oak shavings. On the other hand, statistically significant differences occurred between the length of these briquettes and the length of oak bark briquettes.

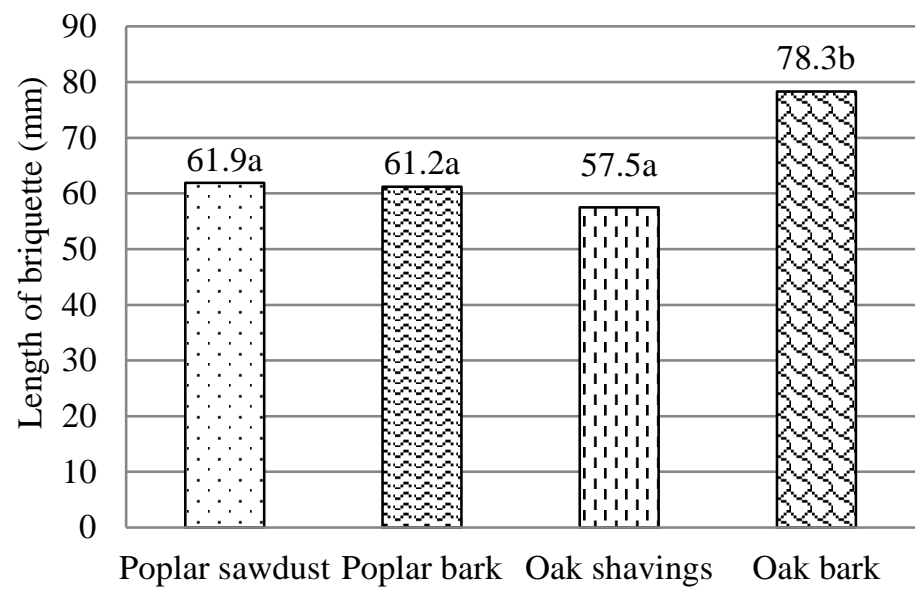

$a, b, c:$ mean values marked with the same letter do not differ statistically significantly at the level $\alpha=0.05$ Source: own work

Figure 1. Average length of produced briquettes

Figure 2 illustrates average mass of obtained briquettes. By analyzing the mass of biofuel produced, oak bark bricks were the heaviest (182.7 g), poplar sawdust - heavier (118.6 g), and poplar bark (110.2 g) and oak shavings (107.6 g) were the lightest. There were no statistically significant differences between the mass of poplar bark and oak shavings. In contrast, in other cases, statistically significant differences were observed between the mass of produced briquettes. 


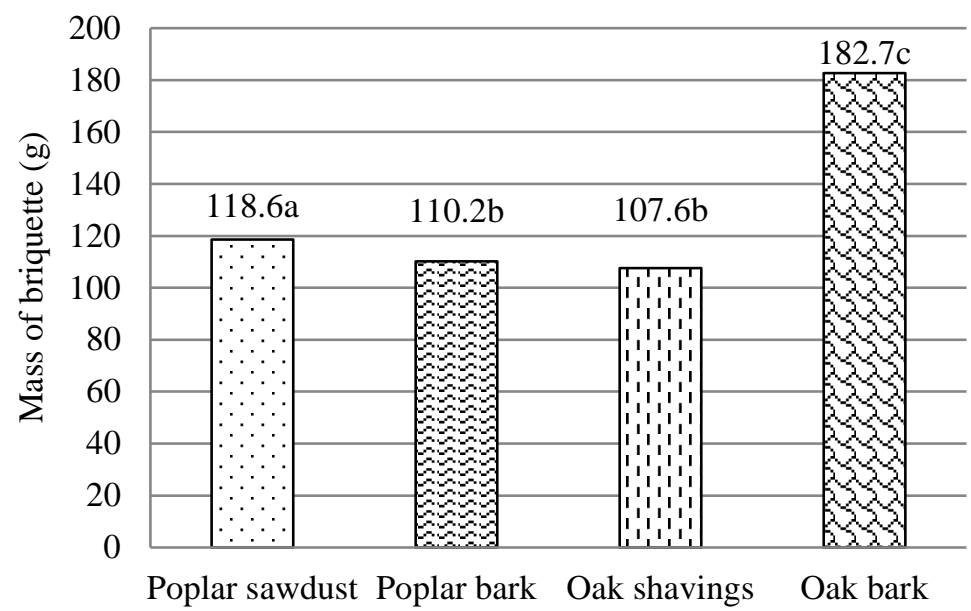

$a, b$, $c$ : mean values marked with the same letter do not differ statistically significantly at the level $\alpha=0.05$

Figure 2. Average mass of produced briquettes

Source: own work

Figure 3 presents average bulk densities of briquettes produced. The highest density was characterized by oak bark briquettes $\left(1190 \mathrm{~kg} \mathrm{~m}^{-3}\right)$. The density of briquettes made from poplar sawdust $\left(978 \mathrm{~kg}^{-3}\right)$ and oak $\left(953 \mathrm{~kg}^{-3}\right)$ was significantly lower than that of briquettes made from poplar bark $\left(918 \mathrm{~kg} \mathrm{~m}^{-3}\right)$. There were no statistically significant differences between bulk density of poplar sawdust and oak shavings. In contrast, for other cases, statistically significant differences were found between densities of produced briquettes.

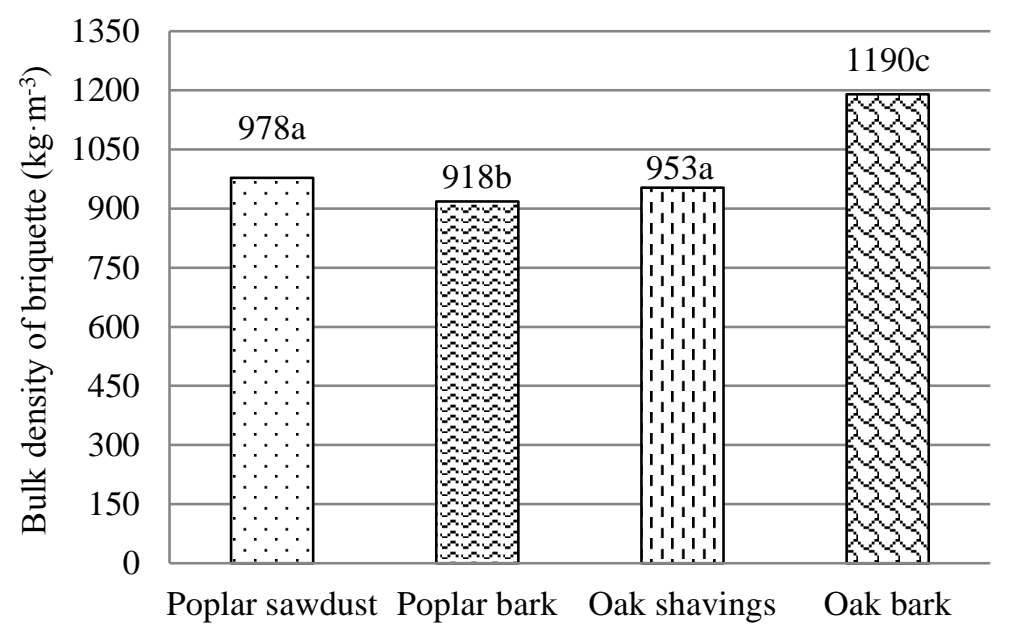

$a, b, c:$ mean values marked with the same letter do not differ statistically significantly at the level $\alpha=0.05$

Figure 3. Average bulk density of produced briquettes

Source: own work

Figure 4 shows the average values of mechanical durability of obtained briquettes. It was found that the largest indicator was showed by oak bark $(97.5 \%)$ and poplar bark briquettes (94.9\%), significantly less - of poplar sawdust (87.8\%) and the lowest - of oak shavings $(78.4 \%)$. There were no statistically significant differences between the durability of poplar bark and oak bark briquettes. However, in the remaining cases, statistically significant differences were found between durability of the produced briquettes. 


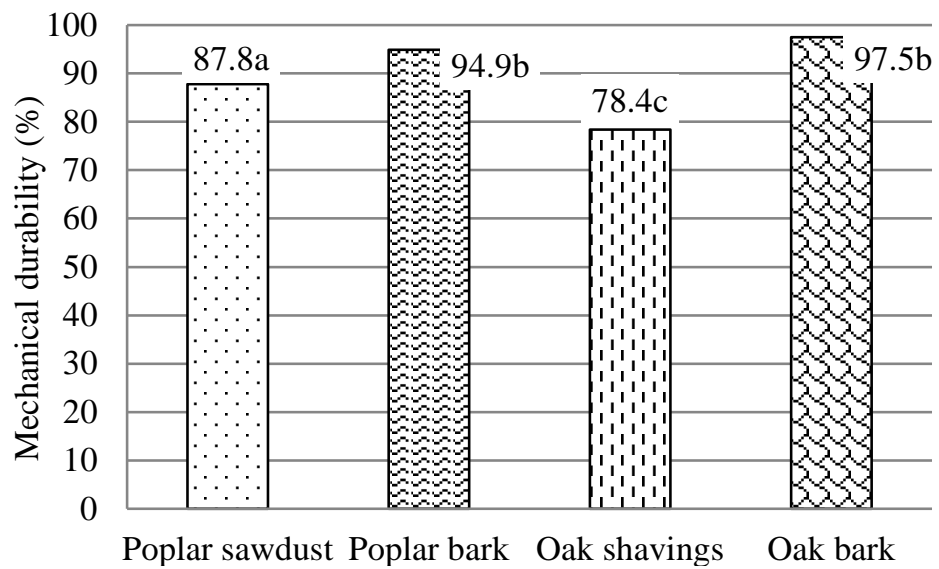

$a, b$, $:$ mean values marked with the same letter do not differ statistically significantly at the level $\alpha=0.05$

Source: own work

Figure 4. Average mechanical durability of produced briquettes

\section{CONCLUSIONS}

Based on the analysis of the obtained results, it was found that the characteristics of produced briquettes were influenced by such factors as the type of raw material, its humidity and fragmentation. The moisture content of wood waste used for the production of briquettes was varied. The lowest moisture content was characterized by oak shavings $(10.7 \%)$ and the highest - oak bark (14.8\%). The calorific value of briquettes from wood waste was slightly differentiated. The lowest heating value was obtained from oat shavings briquettes $15.5 \mathrm{MJ} \cdot \mathrm{kg}^{-1}$, and the highest - from poplar sawdust $16.3 \mathrm{MJ} \cdot \mathrm{kg}^{-1}$. Of the produced briquettes, the lowest bulk density was obtained for the briquette of the poplar bark $\left(918 \mathrm{~kg} \mathrm{~m}^{-3}\right)$ and the highest for the oak bark (1190 $\left.\mathrm{kgm}^{-3}\right)$. The results of mechanical durability tests showed that the lowest indicator was for oak shavings briquettes $(78.4 \%)$, while the highest for oak bark briquettes $(97.5 \%)$. The best qualities of briquettes were found in the case of agglomeration of oak bark, less favorable in the case of poplar sawdust and poplar bark, and the least favorable for oak shavings. Research indicates that the plant material analyzed can be a valuable source of energy. The use of these biofuels is conducive to the achievement of the objectives of sustainable agriculture policy.

\section{REFERENCES}

Demirbas, A. (2004). Combustion characteristics of different biomass fuels. Prog. Energy Combust Sci., Vol. 30, (Issue 2), 219-230.

Dreszer, K., Michałek, R., \& Roszkowski, A. (2003). Energia odnawialna - możliwości jej pozyskiwania i wykorzystania w rolnictwie. PTIR Kraków, ISBN 83-9170-530-7.

Frączek, J. (red.). (2010). Optymalizacja procesu produkcji paliw kompaktowanych wytwarzanych z roślin energetycznych. PTIR Kraków, ISBN 978-83-930818-0-6.

Fournel, S., Marcos, B., Godbout, S., \& Heitz, M. (2015). Predicting gaseous emissions from small-scale combustion of agricultural biomass fuels. Bioresource Technology, 179, 165-172.

Hejft, R., \& Obidziński, S. (2015). Pressure agglomeration of plant materials - pelleting and briquetting (Part II). Journal of Research and Applications in Agricultural Engineering, 60(1), 19-22.

Huiling, L., Xiaobing, L., Hong, W., \& Jingdun, J. (2013). Biomass resources and their bioenergy potential estimation: A review. Renewable and Sustainable Energy Reviews, 26(2013), 344-352. 
Ivanova, T., Kolarikova, M., Havrland, B., \& Passian, L. (2014). Mechanical durability of briquettes made of energy crops and wood residues. Proceedings of $13^{\text {th }}$ International Scientific Conference, Engineering for Rural Development, 13, 131-136.

Kachel-Jakubowska, M., Kraszkiewicz, A., Szpryngiel, M., \& Niedziółka, I. (2013). Analysis of the characteristics of raw materials used in production of solid biofuels. Agricultural Engineering, T.1, 2(143), 103-111.

Kołodziej, B., \& Matyka, M. (red.). (2012). Odnawialne źródła energii. Rolnicze surowce energetyczne. PWRiL Sp. z o.o. Poznań, ISBN 978-83-09-01139-2.

Mc Kendry, P. (2002). Energy production from biomass (part 1): overview of biomass. Bioresource Technology;83, 37-46.

Niedziółka, I. (red.). (2014). Technika produkcji brykietów z biomasy roślinnej. LIBROPOLIS Lublin, ISBN 978-83-63761-38-7.

Niedziółka, I., Szymanek, M., Tanaś, W., Zaklika, B., \& Zarajczyk, J. (2016). Analysis of qualitative properties of briquettes made from plant biomass with a hydraulic piston briquette machine. Journal of Research and Applications in Agricultural Engineering, 61(2), 65-69.

PN-EN 15210-2:2011. Solid biofuels. Determination of mechanical durability of pellets and briquettes. Part 2: Briquettes.

Panwar, V., Prasad, B., \& Wasewar, K. (2011). Biomass residue briquetting and characterization. Journal of Energy Engineering, 137/2, 108-114.

Shawa, M.D., Karunakaranb, C., \& Tabila, L.G. (2009). Physicochemical characteristics of densified untreated and steam exploded poplar wood and wheat straw grinds. Biosystems Engineering, 103(2), 198207.

Zhang, Y., Obrist, D., Zielinska, B., \& Getler A. (2013). Particulate emissions from different types of biomass burning. Atmospheric Environment, Volume 72, 27-35. 